\title{
MEDIA NEWS
}

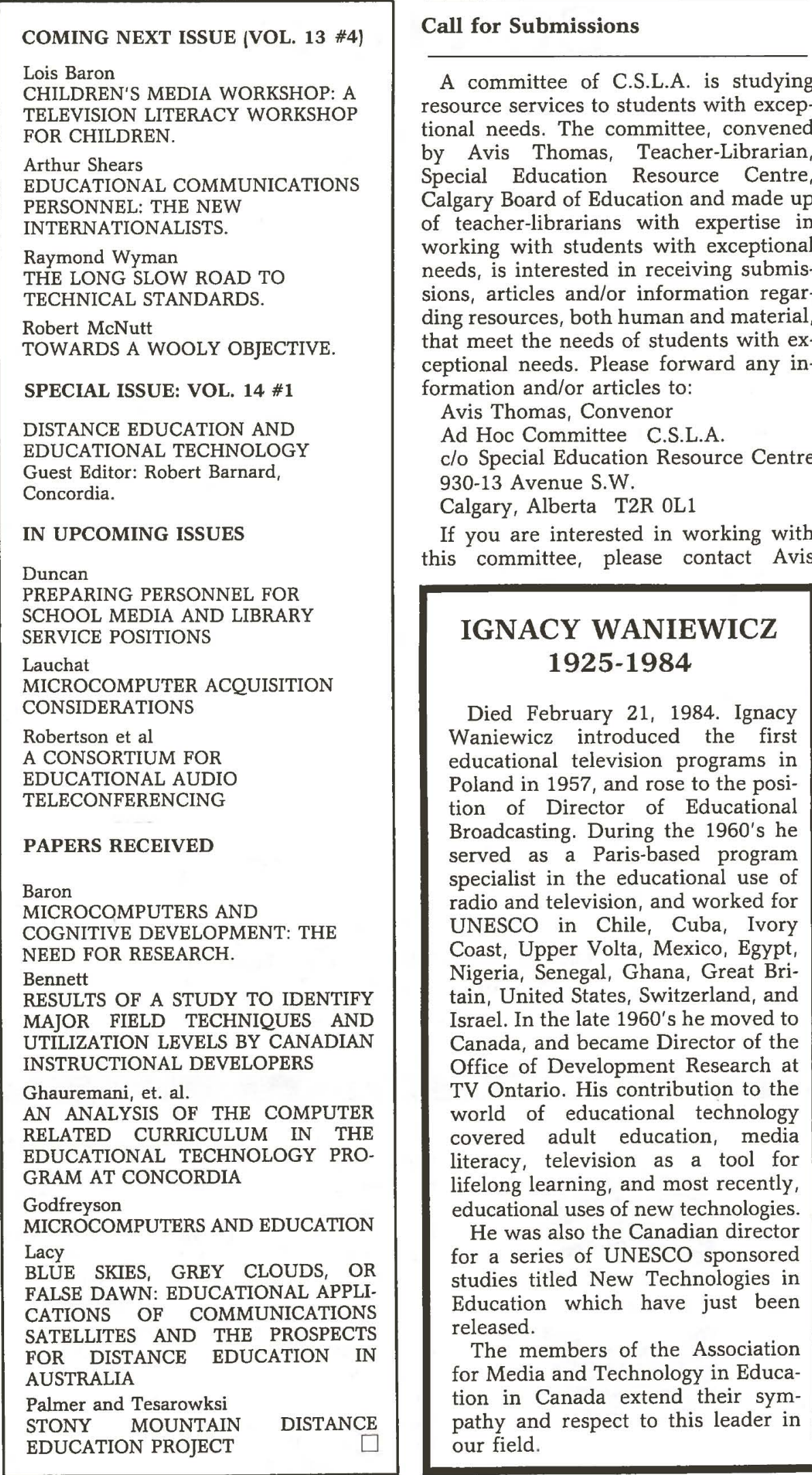

Thomas, Convenor at the above address. New Literature in Educationa

dicated that the Ontario government was

Handbook of Computer Based
Training, by C. Dean and Q. Whitlock. $\left\{\begin{array}{l}\text { to massively support CEMCorp (110 } \\ \text { million on hardware alone) and would } \\ \text { subsidize the purchase of said equipment }\end{array}\right.$ Training, by C. Dean and Q. Whitlock tinues to be the topic of throughout the education field. Here a handbook which can aid you in the analysis, design, implementation an evaluation of computer based traini courses. G.D. Moss, editor of the
British Journal of Educational Technology, was impressed by the clarity of this work, and hails it as "a lifeline for the floundering; a guideline
for the hesitant". This is a 1983 public tion of Kogan Page (London), whose tion of Kogan Page (London), whose
Canadian distributor is Corpus Information Services Ltd., 1450 Don Mill Rd., Don Mills, Ontario M3B 2X7.
Learner-based Evaluation A Learner-based Evaluation o Microcomputer Software, by Vick
Blum Cohen. This is one of severa Blum Cohen. This is one of several
valuable papers in the field of educavaluable papers in the field of educa-
tional technology to emerge from the annual meeting of the American Eductional Research Association in Montreal, April 11-15, 1983. It documents
study in which a team of experts a study in which a team of experts ty, evaluated the quality of educational software. The same software was the given to learners who also evaluated it. Their collective considerations led to the identification of 10 main trends recent software developments. ware development are also given. The form used for collecting feedback software is appended to this document, which available in the ERIC Documen collection as ED 233693

Micronications Software for Microcomputers, by Janet L. Bruman. tions of microcomputer communic tions software packages. Terms such a downloading, protocol and keyboard macros are explained. Suggestions are Continued on page 9 )

Send news items for this column to:

Joe Connor
News Editor, CJEC

c/o D. Hlynka

University of Manitob

VOLUME 13, NUMBER 3, 1984 con Update: by Ontario schools. In order to introduce the ICON to market widely, quickly, and on instituted a "seeding" technique conting of 2 phases. CEMCorp was to have

phr. 1 began in January and allowed e placement of complete ICON systems at 20 test sites at a cost of $\$ 2$ million. These sites ranged from urban centres to
emote northern schools in order to assure a wide range of test conditions. ending in February) under which school boards could purchase an ICON system (\$16 380) for just over $\$ 4000$. A system consists of 3 ICON stations-one with colar monitor, the other two with

CEMCorp was to follow this up with a $d \$ 7670$ for the Lexicon fileserver until end of April before selling the equipent at retail rates beginning in May.

\section{Bionic IBM}

IBM Canada has entered the educalanal computer fray in Ontario with neet the specifications of the Ministry of iducation, placing it in competition with CEM Corp., designs of the Icon ('Bionic Beaver'). The computer would probably
be a redesign of the IBM PC or XT; it is unlikely that the PCir could be adapted to neet the specifications.

omal 80 Standardisation Meeting

An expanded draft standard of the greed upon in Copenhagen, Denmark on December 3, 1983. All current developers Comal 80 systems came together to or the Comal 80 language. The openhagen meeting welcomed three
ew members to the group, a fact which ustrates the rapidly spreading interest

\section{COMPUTER NEWS} hase 2 was to offer a subsidy program or mainframes and micros, as well as for many home computers.

Representatives of the following com

panies took part: Acornsoft (England) Dansk Data Elektronik a/s (Denmark), ps (Denmark), a/s Regnecentralen a 979 (Denmark), TCD Software Engineering Laboratory (Ireland), Unicomal/Commodore (Denmark).

The meeting was chaired by Borge

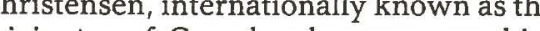
Chiginator of Comal, a language combining the structure of Pscal with the coherent and well-designed programmin language; the implementors cooperate in the Comal 80 Standardisation Group so hat the language will continue to evolve a controlled manner, preventing the dialects. Instead, programs wiltep according to the standard will be portable Copies of the draft standard may be ob-
across all ing ained, at a cost of 55 , from the Secretary ment of Computer Science, Trinity $\mathrm{Col}$ lege, Dublin 2, Ireland.

ontrol Data Software

Control Data Canada has announced a major move into the microcompute than 20 years of development has producd3,000 hours of large-scale computerbot educational software, and Control Data has initiated its adaption to their Plato series of software in an upcoming issue.

oice Input Module Field Test Results Dr. Alonzo E. Hannaford from the completed an evaluative field study for CEE Inc. in Kalamazoo, Michigan on the nationwide distributor recognition device for voice microcomputers. The Voice Input Module permits in-
dividuals to run software (including elecdividuals to run software (including elec-
tronic spreadsheets and word processing programs) as well as to program by voice alone - thus bypassing the keyboard. al software designed for the Apple II Ap- ple II + , Apple IIe, and Franklin Hannaford's field study for MCE observed and interviewed physically handicapped teenagers as they learned how operate the Voice Input Module and as they a variety of software

put Module and the results of this field study contact MCe Inc., 157 S. Kalamazoo
Mall, Suite 250, Kalamazoo, Ml 49007.

Last Column This will be the final COMPUTER
NEWS column edited by Mr. Richard Kenny. The column will be temporarily suspended until a new editor can be
found. Mr. Kenny informs us that other pressing commitments are sus that other must reluctantly give up his work for CJEC. We would like to take the opportunity to thank Rick for his invaluable addition to our journal over the past two and has played an integral role in informing AMTEC readers what is happening in
the microcomputer world. Good luck, Rick, in your future endeavors. - D.H.

Continued on page 14\}

NADIAN JOURNAL OF EDUCATIONAL COMMUNICATION

\begin{tabular}{l} 
CJEC \\
EDITOR \\
The current position of editor of the \\
Canadian Journal of Education expires \\
Fall 1985. So that continuity between \\
editors is maintained, the new editor \\
will act as associate editor for the year \\
preceding. \\
The position allows the individual an \\
opportunity to become actively involv- \\
ed in the mainstream activity of educa- \\
tional technology in Canada. \\
A search committee has been \\
established, and will meet with poten- \\
tial applicants during the London con- \\
ference in June, 1984. \\
Submit references to Bill Hanson, \\
AMTEC president-elect, or to D. \\
Hllyka, CJEC editor, Faculty of \\
Education, University of Manitoba, \\
R3T 2N2. \\
\hline
\end{tabular}




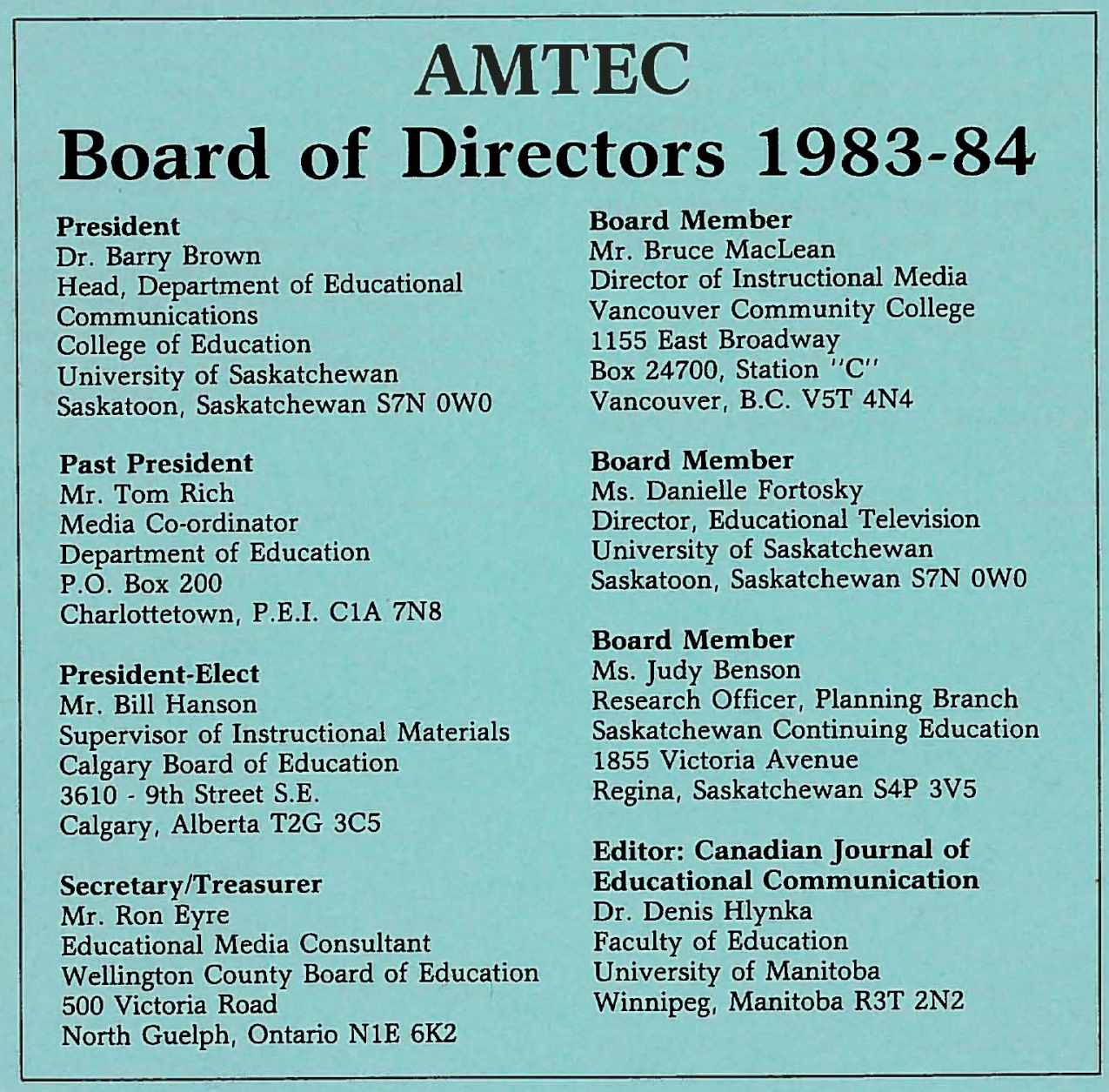

\section{cess}

stage agreed to contribute their share of
development costs; the program will be vailable to other ECNO boards in the ature for the same amount, with proThe program is an interactive one that allows a clerk to work on-line with a reserve curriculum items throughout the chool year calendar; this greatly in creases the feedback to teaching staff of
information needed to facilitate lesson reparation. The system also generate routines as well as providing statistics required to improve library management and plan professional development to
identified needs. Incidentally, the potential is there for schools to book resources directly from school level terminals as hese become available.

The biggest payoff for me, though, is
$\mathrm{pb}$ enrichment. The manual posting and constant resorting of paper required to exto be one of the least rewarding jobs! Now my staff will have a personal contact with someone in each school, and film reserva-
tions will be made as a result of human

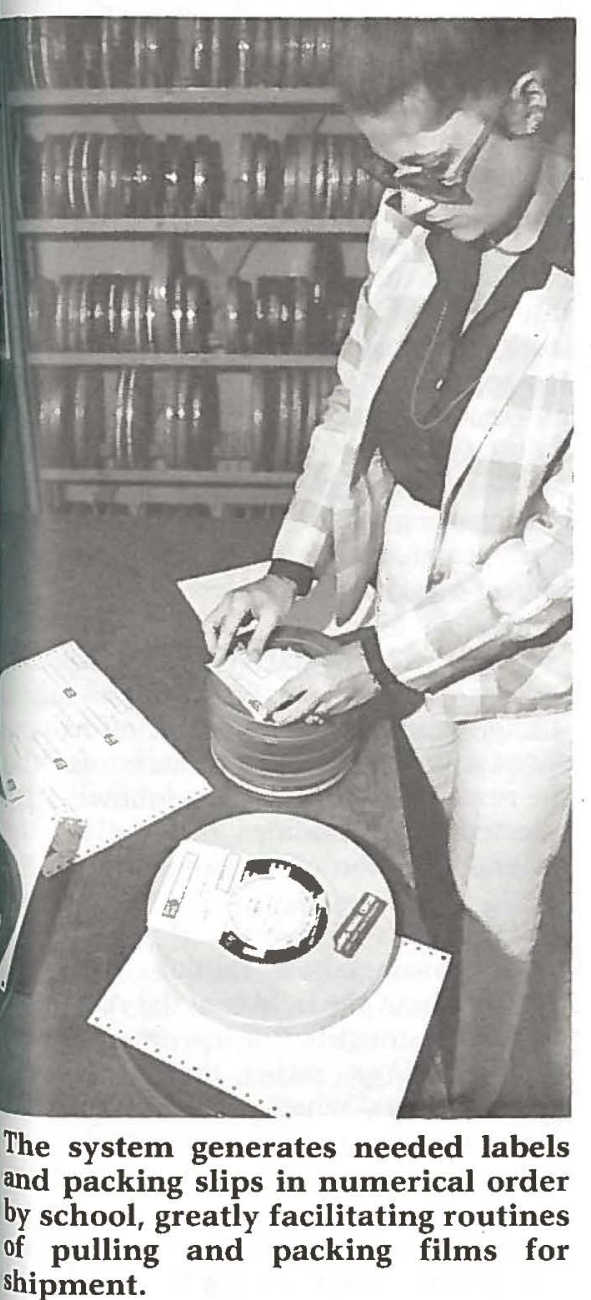

As the program neared completion, I cluded necessary approvals as well as the haring of information with school prinwho had been designated by the liaison cipal. Procedures were explained, with their input encouraged, regarding of the internal local procedures. As result of this dialogue, I prepared a Jun plain the planned change. This is intended to be the last such notice from me. Information about ordering films will now fer relayed through the school hiaison to phance that role, this was intiated with plied to them in quantity for use with Daff at the start of term in September. During the late spring and summer, the program was installed and "gotten-up". Durs was among the first operative, so tween our office and both media computer personnel of the Waterloo County Board. Labels were ordered, a INWATS telephone arranged for to acconn were identified, and corrected up, bu Ordering procedures started Deptember 1, 1983. There was som on citement as nervous school liaisons called booking clerks who had been no more (he newly installed in

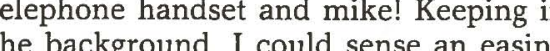
of tension as explanations were made in conversational tones. A great feeling of accomplishment came with the printing of shipping labels and packing slips fo

Amportant part of the process had to be the establishment of film expeditin booking and refurbishing tasks have bee heavily involved in decisions in this regard. All of us are committed to an cidental problems, making revisions and djustments as required. Informal feedack to-date from schools suggests positive reception by both teachers and laisons.

The process has been most rewarding approach when addressing collectivi management problems at any time, but especially when one's own resources seem so limited. The saving of dollars is most obvious but probably the expanding of human resources and ideas, bringing in backgrounds and skills not available
within the organization, is the greatest
benefit.

ways in which they could be effectively

packa. Included is a list of about 75 83 publication of CLASS. ISn is a (CA) firm. The booklet is also available the ERIC Documents collection as

ED 234740 . developments in screen design, data
structure and access control, by Stephen T. Kerr. Another paper presented to the American Educational Research Association's Montreal meeting, this addresses human design requirem information topics as display design, typography, privacy and educational applications are discussed. The author also summarizes the history of videotex development and the outlook for development in the future. The docu ment collection as ED 234739 . DocuThe Information Technologies:

Telidon and education perspectives and possibilities for a new information technology and its impact on education, by Joan McLaren. Telidon, education and society, is the topic of this paper. An explanation of Telidon technology is here illuminated by some useful diagrams. The possible relationthips betwen Telidon and other

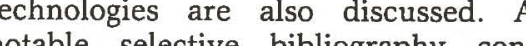
cludes this document, which may be found in the ERIC Document collection as ED 234770 . The paper was prepared in 1983 at the Manitoba Department of Edces in Winiption office in Winnipeg.

tional Technologyary and EducaRosenberg. This dictionary converts a wide range of terms relating to hardware and software in the audiovisual More than 800 terms are listed In ads. tion, a bibliography on educationtion, a bibliography on educational
technology is included, as well as a discussion of criteria used in the selection of equipment for schools and libraries. The dictionary is the 2nd ediand dictionary and ment: a guide ed from the publisher, Libraries Unlimited, P.O. Box 263, Littleton, CO 80160 .

(Continued on page 15) 
New Software Evaluation Instrument The National Science Teachers Association (NSTA) has published a new strument. Prepared by the NSTA Task Force on Assessing Computer-Augmented Science Instructional Materials the new instrument is designed to be used primarily in school-level or district-leve evaluations of science instructional software packages.

the January 1984 issues of NSTA's perodicals, The Science Teacher, Science and Children and the Journal of College Science Teaching. Copies may also be ob-
tained from NSTA, 1742 Connecticut tained from NSTA, 1742 Connecticut

Avenue NW, Washington, DC 20009.
For more information, contact Leopold

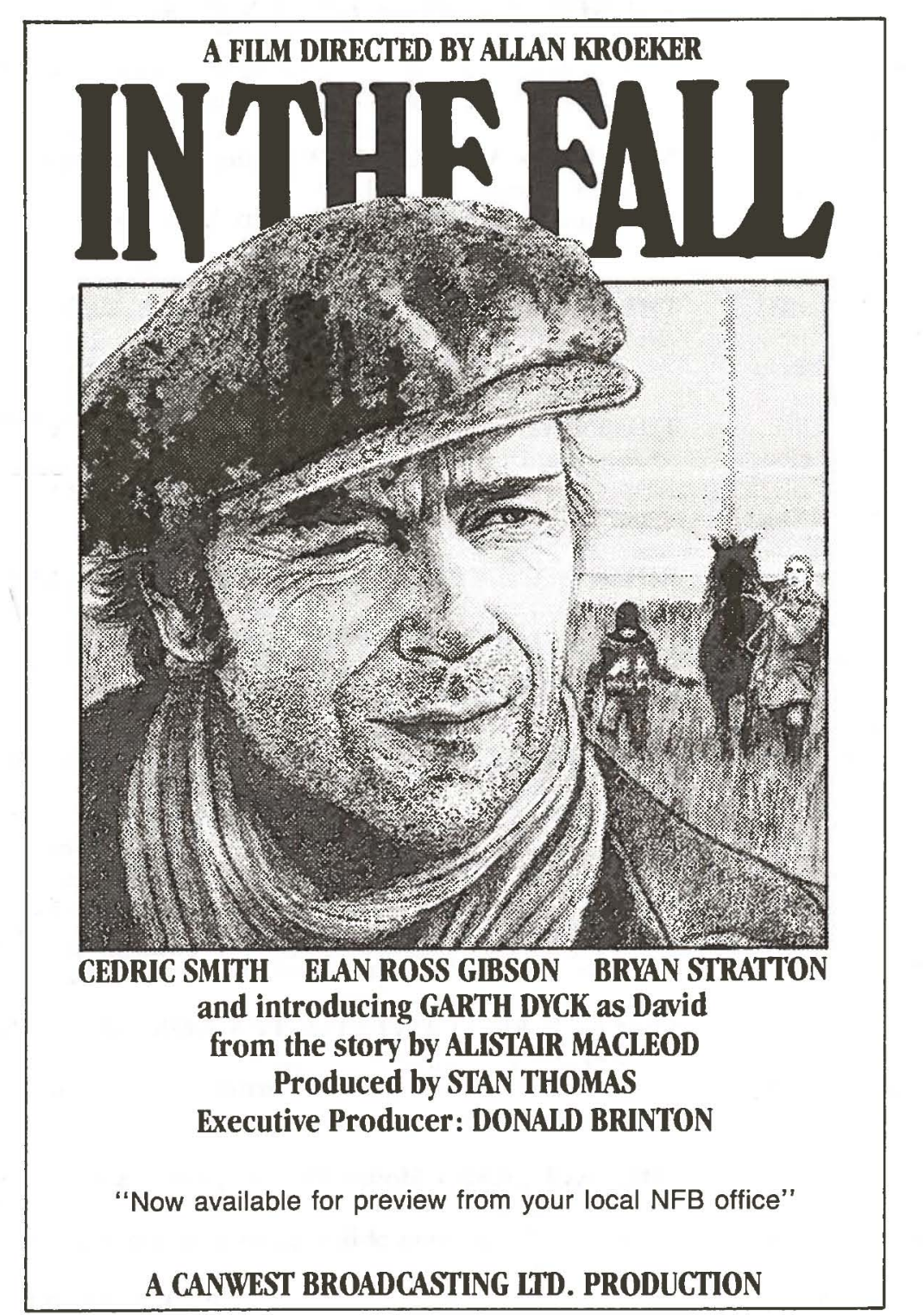

A CANWEST BROADCASTING ITD. PRODUCTION $412 / 624-4821$ ary Offered by Searchmart thousands of individual applications systems software packages online.
E. Klopfer, Prof. of Educ., Chair, NSTA
Task Force, Univ. of Pittsburgh, LRDC Bldg., 3939 O'Hara St., Pittsburgh, PA

Free Access to On-Line Softwar

Searchmart Corp., a South Florida firm information retrieval systems, is offering a Free Access Software Library that lists describes and demonstrates tens oftware will be updated daily and categorized by manufacturer, publisher or vendor, operating systems compatibility, protocol requirements, program inforition, price and ordering The unique feature is the free on-line CORMATIVE RESEARCH Continued from page 11

mance statistics were not compiled. Fur-
ther, the system did not allow the dire entry of text or numeric responses to a question posed in a sequence: the user
could only enter page numbers through a numeric key pad. Of course, these problems are not endemic to Telidon, whose graphic system can be adapted to dif-
ferent host computing facilities ferent host computing facilities and technical configurations. However, they
alert the developers of Telidon systems to the need to ensure that any computerassisted instruction sequences are sufficiently flexible in design and powerful in computing ability to compete with oth available systems.
3.5 Learning $I m$

3.5 Learning Impact

A preliminary evaluation of on suggested that certain Telidon sequences may be effective for some students and ineffective for others. In this study mor advanced students learned as well fro
Telidon as from a traditional teach presentation. However, students Telidon tended to score less well on lear ing tests than students taught by small portion of the grade 9 mathematic
curriculum and allowed students to $g$ curriculum and allowed students to $g$
through the material without teache assistance. Though this study could no employ complete controls on all relate variables, these findings indicate that educational sequences must be designed with careful consideration of
with whom they will be used.

3.6 Designin sequences

3.6 Designing Sequences

possible differential impact of seques

VOLUME 13, NUMBER 3, 19
LOVE'S LABOUR'S LOST

companions come out to meet the ladies negotiations are firm, but towards the end it is obvious that the king is quite taken by Act III. Don Armando is in love

with the dairy maid. He asks his page to and Don Armando discusses love, and the dairymaid's probable virtue. Finally Don Armando, desperately in love, determines to release Costard from his custody, so
that Costard will deliver a message to his love.

Enter Biron. He too, apparently is in love, (Isn't everybody? and he gives
Costard another letter, destined for
Rosaline. Thus Shakespeare contrasts the Rosaline. Thus Shakespeare contrasts the
physical passion on the one hand, with physical passion on the one hand, with
true, honest love, on the other. And Costard now has two letters to deliver. Act IV. There are three scenes in this act. The princess and her ladies are going shooting in the forest, when they are in ter meant for Costard carrying the love letthat the letter be rine. The princess asks pomposity. And, it is, of course, the wrong letter.

The second scene introduces two new characters, the school teacher and the Since she is illiterate, she asks the letter. to read it for her, which he does, and which the school teacher is able to promptly criticise. Again it is the wrong letter, which the characters note, and so they send Jaquenetta to the king!

Scene three. Biron is rediculed by the King, Longaville, and Dumain who see
that Biron is the first to break his a quick philosophic flourish, Biron explains that the only real books are the
eyes of the ladies! argument is eyes of the ladies! argument is en-
thusiasticlly accepted, and the four deterthusiasticlly accepted, and the four deter-
mine to go off and study what should be
studied!

GO PROGRAM

D. Final report of the Brookline logo project: profiles of individual
student work. Logo Memo 54, MIT Logo Group, 1979. unust 1982, 8 (7), 116-134.

D., \& Weir, S. Logo: a computer en-
vironment for learning disabled students. The Computing disabled (8) May 1981.
S. The evaluation and cultivaion of spatial and linguistic cerebral palsy (Memo No. 470). MIT
(Mendiduals with AI Labortaory, Cambridge, October 1979 .

"For women's eyes this doctrine

They are the books, the arts, the That show, contain, and nourish all the world.'

Act V. More fun is made of jargon and the constable schoolmaster, the curate each other full tilt. Moth epitomizes the jargonistic humor in which all indulge, saying that "They have been at a grea feast of languages, and stolen the scraps." the longest word of them all probably the longest word of them all, probably
good enough to enter the Guiness Book of follows, but some essential papers have and her ladies must stay the night. Th

Records ... Honorificabilitudinitatibus.
The final scene returns princess and her ladies. All us to th gifts from their admirers. Upon hearin make an that the men are about Muscovite costume, the ladies determin to disguise themselves. Indeed, the humorous Pagent of the Nine Worthies follows as entertainment. Suddenly the accused of getting as Don Armando is And more bad news arrives. The King of France is dead. The princess resolves to return home immediately. The men all decide to make intentions but the ladies year before they will marry them. Even De will spend three to prove himself . end, love has been proclaimed, but, at least a year must pass before any marriages will take place. Indeed, for the moWe teast, love's labour had been lost. the art/scien discussion with a look at ing up in educational technology of the 1980 's. We have concluded with

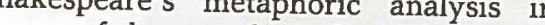
terms of love and study. Who wins? Perhaps we should be the ambiguous, tional technology is mo thane. Educait is a state of mind. And educational technologists will appreciate that in
Love's Labour's Lost, the master playwrite is ... just possibly ... speaking ***

We began our discussion with a look at he art/science dichotomy so often cropping up in educational technology of the
$1980^{\prime}$ s. We have concluded with Sheakespeare's metaphoric analysis in terms of love and study. Who wins?
toris Sheakespeare is predictably ambiguous. 作 it is a state of mind. And educational technologist will appreciate that in Love's just possibly .... speaking to uste is ...

\section{MEDIA NEWS}

page 9

Multimedia for Manitoba?

An association for multi-image in Manitoba is in the process of being other provinces belonging to similar associations with ideas which might help the fledgeling organization, are invited to contact Cliff Kehler, c/o Inland AV, 1645
St. James St., Winnipeg 